omaisesti. Kunnia tästä kuuluu osittain tietysti lehden toimittajille.

Artikkelien yleinen taso oli hyvin korkea, sanoisin ilahduttavan korkea. Tämä kertoo suomalaisen Venäjä-tutkimuksen laajuudesta ja laadukkuudesta. Koska lähes kaikki artikkelit edustivat sellaista alaa, jota en ole muuten seurannut, minulla ei ole kompetenssia arvioida niiden tieteellistä antia kyseisen tieteenalan näkökulmasta. Oikeastaan minulla oli vaikeuksia edes määritellä, mistä tieteenalasta kulloinkin oli kysymys - mutta ajattelin, onko sillä niin väliä. Niinpä yritin kiinnittää huomiota artikkelin tarjoaman näkökulman tuoreuteen ja siihen, mitä uutta tietoa se tuo laajempaan tietoisuuteen.

Ennen kuin perustelen lopullista valintaani, haluaisin antaa kunniamaininnan muutamalle muulle artikkelille. Mielestäni jännittävin artikkeli oli Mia Öhmanin artikkeli "Tarkovskin vapaus". Artikkeli tempaa lukijan mukaansa melkein dekkarin tavoin. Murhaajaa ei yritetä selvittää, vaan kyse on jostain paljon suuremmasta: mitä taiteilijalle merkitsee luomisen vapaus? Neuvostoaika tuo tapahtumien kulkuun oman värinsä. Paineita ei ehkä tule virkavallan taholta, mutta niitä luovat vallitsevat taiteen sisäiset muodit, media ja kollegat. Samanlaista omien rajojensa pohtimista kohtaa taiteilija kaikissa olosuhteissa.

Metodisesti innovatiivisin artikkeli oli Mihail Sokolovin, Nadežda Sokolovan ja Maria Safonovan big data -analyysi pietarilaisten lukumieltymyksistä. Artikkeli perustuu laajan data-aineiston monipuoliseen käsittelyyn. Kirjoittajat itsekin myöntävät, että kyseessä on metodologinen kokeilu. Aineistona on pietarilaisten kirjastonkäyttäjien kirjastokorttien jättämät jäljet, eli siis se mitä he lukevat. Kun dataan liitetään tiettyjä taustamuuttujia, kuten koulutustaso, saadaan jännittäviä tietoja käyttäjien lukutottumuksista. Artikkelin erityisenä ansiona on metodin kriittinen arvio, eli mitä sen avulla saadaan selville ja mitä ei, mitä mahdollisia virhelähteitä on olemassa jne. Uskoisin, että tämäntapaisia artikkeleita tullaan näkemään enemmänkin Idäntutkimus-lehden sivuilla. Big data -analyysi ei korvaa aiemmin käytettyjä metodeja, mutta täydentää niitä mielenkiintoisella tavalla.

Tärkein arvioimani artikkeli oli Maiju Lehdon artikkeli "Ukrainan sota ja taistelu menneisyydestä". Artikkeli avaa täysin uudenlaisen näkökulman Ukrainan sotaan ja taisteluun menneisyydestä. Se perustuu melko pieneen aineistoon, kahdeksan rintamalla taistelleen ukrainalaissotilaan haastatteluun, mutta siitä huolimatta artikkeli avaa täysin uudenlaisen näkökulman Ukrainan konfliktiin. Kulttuurisen muistitutkimuksen metodein paljastetaan, että aseellisen vastakkainasettelun juuret ovat paljon kauempana kuin viime vuosien kielipolitiikassa. Haastattelut auttavat näkemään, mistä ukrainalaisessa patriotismissa ja kansallisen identiteetin rakentamisessa todellisuudessa onkaan kysymys.

Sitten päästäänkin parhaimman artikkelin valintaan. Paras Idäntutkimuksessa vuosina 2017-2018 julkaistu tieteellinen artikkeli on mielestäni Sigrid Kaasik-Krogeruksen "Kuvitellut Pohjoismaat Viron presidenttien puheissa". Idäntutkimus-lehden Itämeri-teemanumerossa (2/2017) julkaistussa artikkelissa pohditaan, miten Viro asemoi itseään tämän päivän maailmassa. Aikaisemman Baltia-narratiivin rinnalle on tullut tarve osoittaa, että Viro on osa Pohjoismaita. Artikkelissa tutkija ei lähde vertailemaan eri presidenttejä keskenään, vaan tarkastelee presidentti-instituutiota kokonaisuudessaan. Virolaiset poliitikot ovat itse huomanneet, että nykyään Virosta puhutaan usein "uutena Pohjoismaana". Se on maan uusi "suuri narratiivi". Artikkeli piirtää lukijan eteen uudenlaisen kuvan eteläisestä naapuristamme. Tämä auttaa meitä käymään hedelmällistä vuoropuhelua virolaisten kanssa. Tällaisen lähestymistavan soisi olevan laajemminkin esillä myös suomalaisessa Venäjän ja Itä-Euroopan tutkimuksessa.

\title{
Kutsu keskustelemaan muuttoliikkeistä ja ylirajaisesta vuorovaikutuksesta
}

Kuluvana vuonna 20. kerran järjestettävä Aleksanteri-konferenssi tarkastelee globaaleja ja ylirajaisia muuttoliikkeitä, yhteisöjä ja kulttuurin virtauksia laajasta näkökulmasta. Konferenssin maantieteellinen alue ulottuu entisen Neuvos- toliiton itäisistä ja eteläisistä alueista Keski- ja Itä-Eurooppaan. Konferenssissa tarkastellaan muuttoliikkeitä ja maahanmuuttajien toimijuutta sosiaalisissa, poliittisissa, kulttuurisissa ja taloudellisissa yhteyksissä, sekä erityisesti 
sitä, miten nämä ilmiöt ja prosessit muokkaavat niin kansainvälisiä rajoja kuin yhteiskunnallista kehitystä maahanmuuton kohde- ja lähtömaissa. Maahanmuutto Euraasian sisällä, sinne ja sieltä pois on osa globaalin etelän ja pohjoisen välisiä virtoja ja vuorovaikutusta, mutta se on ollut myös oleellinen osa historiallisten imperiumien muodostumista.

Historiallisesti maahanmuuton merkitys sellaisilla yhteiskunnan aloilla kuin talous ja kulttuuri on ollut valtava. Se vaikuttaa myös kansalliseen politiikkaan, globaaliin epätasa-arvoon, kaupungistumiseen, paikallisiin yhteisöihin, vaikutteiden leviämiseen, kulttuurisiin innovaatioihin, institutionaaliseen kehitykseen, työmarkkinoihin, koulutukseen, sosiaalipolitiikkaan, kuin myös ulko- ja turvallisuuspolitiikkaan. Paikallistason ja kansallisen maahanmuuttopolitiikan lisäksi tarvitaan myös globaaleja periaatteita ja sääntöjä, etenkin koska poliittisten mullistusten, ympäristöongelmien ja ilmastonmuutoksen riskien kasvaessa voidaan tulevaisuudessa odottaa uusia maahanmuuton virtoja.

20. Aleksanteri-konferenssissa pohditaan muun muassa seuraavia kysymyksiä: millaisia muuttovirtoja ja prosesseja voimme havaita Euraasiassa? Millaisia taloudellisia, kulttuurisia, poliittisia ja strategisia vaikutuksia muuttoliikkeillä on ollut niiden lähtö- ja kohdemaissa? Millainen merkitys euraasialaisilla muuttoliikkeillä on muualla maailmassa? Mitkä ovat nykyhetken euraasialaisten muuttoliikkeiden erityispiirteet? Millaisia haasteita maahanmuuttoon liittyy Euraasiassa ja millaisia kansainvälisiä ratkaisuja näihin voitaisiin löytää? Keitä ovat siirtolaiset ja millaista on heidän elämänsä? Mikä on maahanmuuttajien panos innovaatioihin ja kehitykseen eri aloilla? Kuinka valtioiden rajat ylittävät yhteisöt ja aatteet ovat muuttaneet Euraasiaa? Aleksanteri-konferenssi "Eurasia and Global Migration" järjestetään Helsingin yliopistossa 21. -23.10 .2020 .

Konferenssin pääpuhujina esiintyvät Ulf Brunnbauer (Leibniz Institute for East and Southeast European Studies), Franklin ObengOdoom (Helsingin yliopisto), Madeleine Reeves (University of Manchester), Sergey Ryazantsev (Institute for Social and Political Studies of the Russian Academy of Sciences), Caress Shenk (Nazarbayev University, Kazakstan) ja Teivo Teivainen (Helsingin yliopisto). Lisäksi konferenssiin odotetaan yli 200 eri uravaiheissa olevaa tutkijaa. Ohjelmaan voi ehdottaa 3-4 puhujan paneelia, 3-5 puhujan pyöreän pöydän keskustelua tai yksittäistä esitelmää 15.5.2020 mennessä. Konferenssin kieli on englanti.

Kolmipäiväisestä konferenssista löytyy lisätietoja osoitteesta: https://www.helsinki.fi/en/ conferences/eurasia-and-global-migration 